\title{
Comparison of the Effects of Sports Education and Direct Teaching Models on the Attitude and Cognitive Domain Level of Undergraduate Students
}

\author{
Ender Eyuboğlu ${ }^{1} \&$ Oğuzhan Dalkıran ${ }^{2}$ \\ ${ }^{1}$ Faculty of Sport Sciences, Bartin University, Bartin, Turkey \\ ${ }^{2}$ Faculty of Sport Sciences, Burdur Mehmet Akif Ersoy University, Burdur, Turkey \\ Correspondence: Ender Eyuboğlu, Faculty of Sport Sciences, Bartin University, Bartin, Turkey. E-mail: \\ endereyuboglu@hotmail.com
}

Received: November 15, 2019 Accepted: February 26, 2020 Online Published: March 1, 2020

doi:10.5539/jel.v9n2p191 URL: https://doi.org/10.5539/jel.v9n2p191

\begin{abstract}
The purpose of this study was to compare the effects of the sports education model and the direct teaching model used in badminton courses on the attitudes of undergraduate students towards the course and its permanence on cognitive domain skills. The study group consisted of a total of 45 undergraduate students, 24 of whom were experimental groups and 21 were control groups. In the study, for collection of data, the "Intrinsic Motivation Inventory" which developed by Ryan (2000), adapted to Turkish by Çalışur after being tested for validity and reliability (Çalışur \& Demirhan, 2013) and the "Badminton Cognitive Domain Information Form" which was prepared by the course instructor were used. Descriptive statistical analysis was used for data analysis of attitudes of groups after application, but, bacause of the lack of a normal distribution, the "Mann Whitney U" test was used for the significance of the difference between the cognitive domain and the permanence of learning, As a result; significant differences were determined between the students' interest/enjoyment aspect and the permanence of cognitive learning, whereas significant differences were not detected in the aspects of perceived competence, value/benefit, effort/importance, job perception/perceived choice and pressure/tension.
\end{abstract}

Keywords: sports education model, direct teaching model, cognitive domain, permanent learning

\section{Introduction}

Examining the expectations of today's education system and the behaviors that the learner wants to gain is an important effort to understand and solve the problems of the system. It could be said that the inclusion of the learner in the learning process which makes learning more willing and rememberable, transferring the obtained knowledge and skills to his/her life, thinking critically, discovering information, taking responsibility and empathizing are the main goals of today's education system. The acquisition of these skills is possible through the effective use of teaching methods/approaches/models.

The teacher-centered direct teaching model is also known as open expression, active teaching. This model is a teaching method that requires an organized program and to be systematic in the use of tools, aims to provide the mastership in particular skills and high-level participation (Güzel, 1998). Lack of motivation displayed by students in physical education lessons, passing the class without providing basic skills at an adequate level, not comprehending the game forms at an adequate level, not reflecting it to the sports background, domination of skilled students in the groups and a low inclusion of other students to find a suitable learning environment have reinforced the pursuit of a new model (Çelen, 2012).

Sports education model; differs from physical education activities carried out with traditional methods in terms of the purpose, process and evaluation aspects. The primary objectives of the model are to train educated, skillful and enthusiastic sports people. It differs from direct teaching that focuses on sports skills, rules and regulations (Glotova, 2011). When the importance of the priority objectives is considered; a knowledgeable player understands the value of the rules, habits, and traditions of the sport and knows the difference in the various sports. A skillful player; with the knowledge required by the game, will understand and apply the strategies and have sufficient information to participate in the game. An eager player; will be a participant and will show behavior that shall maintain the sports culture and increase its value (Siedentop, 1994). 
When the studies in the literature are examined; it can be said that the sport education model provides an increase in knowledge and that the findings are mostly positive (Ormond, Christie, Barbieri, \& Schell, 2002; Browne, Carlson, \& Hastie, 2004; Hastie \& Curtner-Smith, 2006; Hastie \& Sinelnikov, 2006; Mohr, Townsend, Bulger, Rairigh, \& Mohr, 2006). However, few studies examine the effect of sports education model on the permanence of cognitive skills is noteworthy. At the same time, as the sports education model is applied in many countries with a large rate of positive results, it is thought that using this model in the education of physical education teacher candidates might be important. Therefore, the aim of the research is to compare the effect of sports education model and direct teaching model used in badminton courses of undergraduate students on the student attitudes in the course and the permanence of cognitive domain skills.

\section{Materials and Methods}

\subsection{Research Model}

In the study, an experimental design, which investigates cause-and-effect relationships between variables, was used. In the study, the independent variable is the badminton training programs prepared by the sports education model and the direct teaching model; whereas the dependent variables consist of the students' cognitive learning levels and its permanence (cognitive domain), and the attitudes towards the badminton course (affective domain).

\subsection{Study Group}

The experimental group of the study consists of a total of 24 undergraduate students, 11 girls and 13 boys, taking badminton class in the Mehmet Akif Ersoy University, School of Physical Education and Sports, Department of Physical Education and Sports Teaching, whereas the control group of the study consists of a total of 21 undergraduate students, 9 girls and 12 boys, that are taking badminton class in the Department of Sports Management. The study group consisted of a total of 45 undergraduate students, 24 of whom were experimental groups and 21 were control groups.

\subsection{Instrumentation}

As a first instrument; with the experimental group, badminton lessons were taught for 14 weeks using the sports education model. In the first five weeks, basic information-skills about the outlines of the model and the selected badminton branch were given. In the second five weeks, teams were formed, and distribution of tasks was made, and the groups began to implement their own plans. The last four weeks included the preparation tournament and celebrations. With the control group, badminton classes were conducted for 14 weeks using the direct teaching model. At the end of the 14-week process, the 'Intrinsic Motivation Inventory' was applied to the experimental and control group students. Experimental group students were also given the tasks of coaching, refereeing, team captain, health representative, statistician, press representative, and organization committee member. In order to determine the permanence of learning, 6 months after the application, "badminton cognitive domain information form" was applied to the experimental and control groups.

As a second instrument in the study; for collection of data, the "Intrinsic Motivation Inventory" which developed by Ryan (2000), adapted to Turkish by Çalışkur after being tested for validity and reliability (Çalışur \& Demirhan, 2013) was used. The "Intrinsic Motivation Inventory" consists of 32 attitude statements. These expressions were prepared according to the 7-point Likert scale, starting from expressions such as "very untrue", to "somewhat" to "very true". The inventory consists of the aspects of "interest/enjoyment", "perceived competence", "perceived choice", "value/benefit", "effort/importance", "business perception", "pressure/tension". Score calculation is equal to the point value used in the evaluation of the plain expression in the inventory (for example, if 1 , it is 1 , if 7 , it is 7 ). In the inventory, the expressions $3,4,13,15,18,20,23,24$, 26 are reversed. The scores corresponding to these expressions are transformed into a new score by subtracting from 8 .

As a third instrument; the "Badminton Cognitive Domain Information Form" prepared by the course instructor was used for collection of data. The badminton cognitive domain information form consists of 13 multiple-choice questions and is evaluated over 100 points.

\subsection{Data Analysis}

Descriptive statistical analysis was used for data analysis of attitudes of groups after application, but, bacause of the lack of a normal distribution, the "Mann Whitney U" test was used for the significance of the difference between the cognitive domain and the permanence of learning, In the conducted analyses, the significance level was accepted as 0.05 . 


\section{Findings}

Table 1. Mann-Whitney $U$ test results of the interest/enjoyment aspect according to the method applied

\begin{tabular}{llllll}
\hline Interest Enjoyment & $\mathrm{N}$ & Mean Rank & Rank Sum & $\mathrm{U}$ & $\mathrm{p}$ \\
\hline Experimental Group & 24 & 27.77 & 666.50 & 137.50 & $.008^{*}$ \\
Control Group & 21 & 17.55 & 368.50 & & \\
\hline
\end{tabular}

Note. ${ }^{*} \mathrm{p}<0.05$.

It was found that there was a significant difference between the experimental and control groups in terms of the interest/enjoyment aspect attitudes towards the badminton lessons $(U=137.500 ; p<.05)$. Considering the mean ranks, the level of interest/enjoyment of the experimental group (Mean rank=27.77) is higher than the control group (Mean rank=17.55). According to this result, it can be said that the sports education model affects the level of interest/enjoyment more positively than the direct teaching model.

Table 2. Mann-Whitney U test results of the perceived competence aspect according to the method applied

Note. $\mathrm{p}>0.05$.

\begin{tabular}{llllll}
\hline Perceived Competence & $\mathrm{N}$ & Mean Rank & Rank Sum & $\mathrm{U}$ & $\mathrm{p}$ \\
\hline Experimental Group & 18 & 24.83 & 596.00 & 208.00 & .315 \\
Control Group & 11 & 20.90 & 439.00 & & \\
\hline
\end{tabular}

It was determined that there was no significant difference between the experimental and control groups in terms of the perceived competence aspect attitudes towards the badminton lessons $(U=208.00 ; p>.05)$. According to this result; it can be said that both the experimental and the control group students' ability to see themselves as competent and the feeling of self-confidence was above average as a result of the applied models.

Table 3. Mann-Whitney $U$ test results of the perceived choice aspect according to the method applied

\begin{tabular}{llllll}
\hline Perceived Choice & $\mathrm{N}$ & Mean Rank & Rank Sum & $\mathrm{U}$ & $\mathrm{p}$ \\
\hline Experimental Group & 24 & 20.65 & 495.50 & 195.50 & .180 \\
Control Group & 21 & 25.69 & 539.50 & & \\
\hline
\end{tabular}

Note. $\mathrm{p}>0.05$.

It was determined that there was no significant difference between the experimental and control groups in terms of the perceived choice aspect attitudes towards the badminton lessons $(U=195.50 ; p>.05)$.

Table 4. Mann-Whitney $U$ test results of the value/benefit aspect according to the method applied

\begin{tabular}{llllll}
\hline Value/Benefit & $\mathrm{N}$ & Mean Rank & Rank Sum & $\mathrm{U}$ & $\mathrm{P}$ \\
\hline Experimental Group & 24 & 23.42 & 562.00 & 242.00 & .819 \\
Control Group & 21 & 22.52 & 473.00 & & \\
\hline
\end{tabular}

Note. $\mathrm{p}>0.05$.

It was also revealed that there was no significant difference between the experimental and control groups in terms of the value/benefit aspect attitudes towards the badminton lessons $(U=242.00, p>.05)$. According to this result; it can be said that both the experimental and control group students' attitudes about the necessity and usefulness of the subject are above average as a result of the applied models.

Table 5. Mann-Whitney $U$ test results of the effort/importance aspect according to the method applied

Note. $\mathrm{p}>0.05$.

\begin{tabular}{llllll}
\hline Effort/Importance & $\mathrm{N}$ & Mean Rank & Rank Sum & $\mathrm{U}$ & $\mathrm{p}$ \\
\hline Experimental Group & 24 & 20.73 & 497.50 & 197.50 & .210 \\
Control Group & 21 & 25.60 & 537.50 & & \\
\hline
\end{tabular}


According to the Table 5, there was no significant difference between the experimental and control groups in terms of the effort/importance aspect attitudes towards badminton classes $(U=197.50, p>.05)$. According to this result; it can be said that both the experimental and the control group students' effort and well-being attitudes are above average as a result of the applied models.

Table 6. Mann-Whitney U test results of the work perception aspect according to the method applied

Note. $\mathrm{p}>0.05$.

\begin{tabular}{llllll}
\hline Work Perception & $\mathrm{N}$ & Mean Rank & Rank Sum & $\mathrm{U}$ & $\mathrm{p}$ \\
\hline Experimental Group & 18 & 20.31 & 487.50 & 187.50 & .130 \\
Control Group & 11 & 26.07 & 547.50 & & \\
\hline
\end{tabular}

When looked at the Table 6, there was no significant difference between the experimental and control groups in terms of the work perception aspect attitudes towards the badminton lessons $(U=187.50 ; p<.05)$.

Table 7. Mann-Whitney U test results of the pressure/tension aspect according to the method applied

\begin{tabular}{llllll}
\hline Pressure/Tension & $\mathrm{N}$ & Mean Rank & Rank Sum & $\mathrm{U}$ & $\mathrm{p}$ \\
\hline Experimental Group & 24 & 23.54 & 565.00 & 239.00 & .764 \\
Control Group & 21 & 22.38 & 470.00 & & \\
\hline
\end{tabular}

Note. $\mathrm{p}>0.05$

It was also found that there was no significant difference between the experimental and control groups in terms of the pressure/tension aspect attitudes towards badminton lessons $(U=239.00 ; p>.05)$. Considering that the items related to the factor in the inventory is regarding the pressure the students feel in lessons, it can be said that the attitude of the teacher is effectual.

Table 8. Mann-Whitney $U$ test results of cognitive learning permanence according to the method applied

\begin{tabular}{llllll}
\hline Knowledge Level & $\mathrm{N}$ & Mean Rank & Rank Sum & $\mathrm{U}$ & $\mathrm{p}$ \\
\hline Experimental Group & 24 & 27.73 & 665.50 & 138.50 & $.009^{*}$ \\
Control Group & 21 & 17.60 & 369.50 & & \\
\hline
\end{tabular}

Note. ${ }^{*} \mathrm{p}<0.05$.

In the Table 8, it was found that there was a significant difference between the experimental and control groups in terms of the cognitive learning permanence of badminton lessons $(U=138.500 ; p<.05)$.

When the mean scores were considered, the cognitive learning persistence of the experimental group (Mean Rank=27.73) was higher than the control group (Mean Rank=17.60). According to this result; it can be said that the sports education model has a more positive effect on permanent learning than the direct teaching model.

\section{Conclusion and Discussion}

According to the results of the study, it was found that the sports education model affected the level of interest/enjoyment more positively than the direct teaching model. As a similar result, Wallhead and Ntoumanis (2004), in their study on high school students, found that there was an increase in the students' level of enjoyment in the conducted lessons made with the sports education model while there was no significant increase in the students' level of enjoyment in the conducted lessons made with the Direct Teaching Model. In regard to the effect of the sport education model on the affective domain; MacPhail et al. (2004), Schneider and Marriott (2010), Sinelnikov and Hastie (2010) found in their studies conducted with students from different age groups that attitude towards and interest in the lesson developed more positively compared to the direct teaching model. Again, in a similar study, Perlman (2012) stated that students which previously had no interest towards the lesson had a positive change in their perception regarding the aspects of interest-enjoyment when the sports education model was used. Liang et al. (2016) stated that the sports education model increased the self-motivation of the students and met the psychological needs of the students in order to encourage their participation in physical education.

Cuevas et al. (2016) emphasized that the sports education model has led to significant improvements in intrinsic 
motivation and its suitability to improve self-assessment behaviors in Physical Education. In a similar study; Perlman (2012) stated that there was a significant change in self-assessment skills for students participating in the sports education model, and that the implementation of the sports education model could be used as a means of supporting students' social commitments and motivation to engage in sports-based activities. The effects of sports education model on intrinsic motivation and self-evaluation behaviors were discussed. Considering that there are other factors affecting these emotional states such as emotional intelligence, complementary studies may be necessary. Sarıkabak and Çelebi (2019) found a negative relationship between the emotional states and problem-solving skills of the students of the faculty of sports sciences. As the emotional intelligence levels of the students increased, their problem-solving skills improved in their study.

According to the results of the study conducted by Mohr et al. (2006) to determine the effect of the sports education model on sports knowledge; in the basketball contents knowledge scores conducted during the middle of the study and at the end of the study, significant differences were obtained in favor of the final test in the group, and in favor of the sports education model amongst the groups, and it was determined that the sports education model was an effective educational approach to gaining content knowledge. The findings of the study by Layne and Piipari (2015) show that the sports education model is an effective pedagogical approach to improve the game performance and sports content knowledge of undergraduate students. According to the study conducted by Çelen (2012) about the cognitive domain, there is a statistically significant difference between the cognitive domain pre-test and post-test values of the control and experimental groups for the volleyball course in favor of the post-test values, and that when the beginning and end behaviors of the experimental and control group students were compared, a significant increase in favor of end behavior was recorded. It has been shown in various studies that the sport training model is effective and necessary for athletes, but it can also be considered and adapted as distant learning for national athletes who spend most of the year in camps. In the study done by Bozkuş (2014), the problems of absences of elite athletes in their classes at universities lead to fail their exams because they don't attend the courses and have lack of subject learning. This situation also affects student athletes' sportive performances in a negative way.

It can be said that the main result of the research is the effectiveness and ensuring of the permanence in learning using the sports education model rather than the cognitive domain development during or at the end of the implementation of the model. As a result; it can be said that through good planning about each subject and using the sports education model, lessons can be made to be fun as well as making students actively participate and take personal responsibilities while ensuring permanence in learning in all activities of physical education.

\section{Acknowledgements}

We are very grateful to experts for their appropriate and constructive suggestions to improve this template.

\section{References}

Bozkuş, T. (2014). A research on identifying the need for distance education for national athletes who study in school of physical education and sport. Turkish Online Journal of Distance Education, 15(3), 21, https://doi.org/10.17718/tojde.61911

Browne, T. B. J., Carlson, T. B., \& Hastie, P. A. (2004). A comparison of rugby seasons presented in traditional and sport education formats. Europian Physical Education Review, 10(2), 199-214. https://doi.org/10.1177/1356336X04044071

Çalışkur, A., \& Demirhan, A. (2013). İçsel güdülenme envanteri dilsel eşdeğerlik, güvenirlik ve geçerlik çalışması. Uşak Üniversitesi Sosyal Bilimler Dergisi, 6(4), 52-74. https://doi.org/10.12780/UUSBD274

Çelen, A. (2012). Spor ĕgitimi modeli ile işlenen voleybol derslerinin öğrencilerin bilişsel, duyuşsal ve psikomotor erişi düzeylerine etkisi. Yayınlanmamış Doktora tezi, Gazi Üniversitesi Eğitim Bilimleri Enstitüsü, Ankara.

Cuevas, R., García-López, L. M., \& Serra-Olivares, L. M. J. (2016). Sport education model and self-determination theory: An intervention in secondary school children. International Journal of Fundamental and Applied Kinesiology, 48(1), 30-38. https://doi.org/10.26582/k.48.1.15

Glotova, O. N. (2011). Sport education model in Russian schools: Professional development and effective teaching for pre-service teachers. A dissertation submitted to the Graduate Faculty of Auburn University in Partial Fulfillment of the requirements for the Degree of Doctor of Philosophy Auburn, Alabama. USA.

Güzel, R. (1998). Alt özel sinıflardaki öğrencilerin sesli okudukları öyküyü anlama becerisini kazanmalarında doğrudan öğretim yöntemiyle sunulan bireyselleştirilmiş okuduğunu anlama materyalinin etkililiği. 
Yayınlanmamış Doktora Tezi, Gazi Üniversitesi Sosyal Bilimler Enstitüsü, Ankara.

Hastie, P. A., \& Curtner-Smith, M. D. (2006). Influence of a hybrid sport education-games for understanding model on one teacher and his students. Physical Education and Sport Pedagogy, 11(01), 1-27. https://doi.org/10.1080/17408980500466813

Hastie, P. A., \& Sinelnikov, O. A. (2006). Russian students' participation in and perceptions of a season of sport education. Europian Physical Education Review, 12(2), 131-150. https://doi.org/10.1177/1356336X06065166

Layne, T. E., \& Piipari, S. Y. (2015). Effects of the sport education model on university students game performance and content knowledge in basketball. Journal of Sports Research, Conscientia Beam, 2(2), 24 36. https://doi.org/10.18488/journal.90/2015.2.2/90.2.24.36

Liang, Y., Zhang, J., Cui, Y., \& Yuan, R. (2016). Experimental study for cultivating college students' sports motivation in sport education model. Advances in Physical Education, 6, 169-177. https://doi.org/10.4236/ape.2016.63019

MacPhail, A., Kirk, D., \& Kinchin, G. (2004). Sport education: promoting team affiliation through physical education. Journal of Teaching in Physical Education, 23, 106-122. https://doi.org/10.1123/jtpe.23.2.106

Mohr, D. J., Townsend, J. S., Bulger, S. M., Rairigh, R. M., \& Mohr, C. (2006). Effect of a pedagogical approach to a sport education season on sport literacy. AAHPERD National Convention and Exposition Salt Lake City. Retrieved from http://aahperd.confex.com/aahperd/2006/finalprogram/paper_8702.htm

Ormond, T., Christie, B., Barbieri, D., \& Schell, B. (2002). A comparison of sport education and the traditional unit approach: game play, activity levels, and knowledge. Research Quarterly for Exercise and Sport, 73(Suppl.), A-77.

Perlman, D. (2012). The influence of the Sport Education Model on Amotivated Students' In-Class Physical Activity. European Physical Education Review, 18, 335-345. https://doi.org/10.1177/1356336X12450795

Ryan, M., \& Deci, E. L. (2000). Intrinsic and extrinsic motivations: Classic Definitions and New Directions. Contemporary Educational Psychology, 25, 54-67. https://doi.org/10.1006/ceps.1999.1020

Sarikabak, M., \& Çelebi, M. (2019). Investigation of Emotional Intelligence Levels and Problem-Solving Skills of Faculty of Sport Sciences Students. 11th International Sport Community Symposium, Antalya (Ekim).

Schneider, R. C., \& Marriott, S. T. (2010). Applying sport education model to basketball. Journal of Physical Education, Recreation \& Dance, 81(2), 15-17. https://doi.org/10.1080/07303084.2010.10598427

Siedentop, D. (1994). Sport education: quality P.E. through positive sport experiences. Champaign, IL. Human Kinetics.

Sinelnikov, O. A., \& Hastie, P. A. (2010). Students' autobiographical memory of participation in multiple sport education seasons. Journal of Teaching in Physical Education, 29, 167-183. https://doi.org/10.1123/jtpe.29.2.167

Wallhead, T. L., \& Ntoumanis, N. (2004). Effects of a sport education intervention on students' motivational responses in physical education. Journal of Teaching in Physical Education, 23, 4-18. https://doi.org/10.1123/jtpe.23.1.4

\section{Copyrights}

Copyright for this article is retained by the author, with first publication rights granted to the journal.

This is an open-access article distributed under the terms and conditions of the Creative Commons Attribution license (http://creativecommons.org/licenses/by/4.0/). 